\title{
Problems in respect of adherence to disclosure requirements regarding interim financial reporting in South Africa - An overview and recommendations to solve these problems
}

\author{
JGI Oberholster \\ School of Accountancy \\ University of Pretoria
}

\author{
MJ Nieuwoudt \\ School of Accountancy \\ University of Pretoria
}

\begin{abstract}
For years, interim financial reports in South Africa were regulated by the South African Companies Act No. 61 of 1973 (as amended) (i.e. statutory requirements) and by the Johannesburg Stock Exchange (JSE) Listing Requirements (i.e. regulatory requirements) only. However, on the international front, major progress was being made in respect of improving the quality of interim financial reporting. South Africa soon followed suit and issued its own accounting statement, AC 127, which is based on the international standard (IAS 34).

The School of Accountancy at the University of Pretoria commenced a research project on interim financial reporting in 1997 to investigate compliance with related reporting requirements. This paper is a product of the project. The purpose of the study reported in this paper was to:
\end{abstract}

- Compare the requirements stated in IAS 34 and AC 127 with the local regulatory and statutory requirements, to determine whether these requirements are duplicated and to establish in which respect the accounting standards require additional disclosure requirements.

- Provide an overview of the extent to which companies listed on the JSE adhered to IAS 34 and AC 127 and complied with regulatory and statutory requirements in their interim financial reports in the period 1997 to 1999.

- Make recommendations regarding the improvement of local statutory and regulatory disclosure requirements.

\section{Key words}




\section{Introduction and background}

South Africa, together with other developing countries, is competing for international investments. It is for this reason that it is important to present financial information in a way that renders the information internationally acceptable and comparable (Nieuwoudt \& Koen 1999:188). In the South African environment, the Harmonization and Improvement Project of the South African Institute of Chartered Accountants (SAICA) has contributed to the international acceptance and comparability of financial information. SAICA's Harmonization and Improvement Project closely followed the project launched by the International Accounting Standards Committee (IASC) to prepare a set of accounting standards that are internationally acceptable (Mockler 1993:3; Blumberg 1995:3).

For many years (until the end of 1998), the contents of interim financial reports in South Africa were only regulated by Schedule 4 of the South African Companies Act, No. 61 of 1973 (as amended) and section 8 of the Johannesburg Stock Exchange (JSE) Listing Requirements (JSE Listing Requirements; Nieuwoudt \& Koen 1999:187). However, on the international front, major progress has been made in respect of improving the quality of interim financial reports to ensure that the reports will be comparable globally (compare IASC 1995, IASC 1996a-c and IASC 1997b). The process of improving the reports commenced in 1996 and culminated in an international accounting standard on interim financial reporting (IAS 34 (IASC 1998)), issued by the International Accounting Standards Committee in February 1998. South Africa, as part of SAICA's Harmonization and Improvement Project, soon followed suit and issued its own accounting standard, namely AC 127 (SAICA 1998c). Because the only difference between the international and the local standard is an additional treatment of a change in accounting policy (which is permitted by IAS 34, but not by AC 127 (SAICA 1998c)), it was assumed for the purposes of the present research project that these standards are the same.

To monitor companies' compliance with statutory and regulatory requirements as well as with the accounting standard in respect of interim financial reporting, the School of Accountancy at the University of Pretoria, South Africa, launched a research project on interim financial reporting in 1997. In terms of the project, the top 50 listed companies in the industrial sector of the Johannesburg Stock Exchange (JSE) were selected in each year and their interim reports analysed. Research has revealed compliance with statutory and regulatory requirements to be lower than expected (given that non-compliance may result in both penalties and fines being imposed in terms of the Companies Act and in delisting from the JSE). The same research also revealed that adherence to accounting standards (both local and international) had improved in each consecutive year (Koen et al 1998-2000). 
This study compares the reporting requirements of accounting standards for interim reporting with the statutory and regulatory reporting requirements. Furthermore, the study indicates weaknesses in the current reporting practices, identifies possible reasons for the weaknesses and makes recommendations regarding the elimination of these weaknesses and the improvement of interim reporting in South Africa.

\section{Research objectives}

The purpose of this study was to:

- $\quad$ Compare the requirements contained in IAS 34 and AC 127 with the local regulatory and statutory requirements, determine duplication of these requirements and indicate where the accounting standards require additional disclosure.

- $\quad$ Provide an overview of the extent to which companies listed on the JSE adhered to IAS 34 and AC 127 in their interim financial reports in the period 1997 to 1999.

- Indicate the extent to which these companies complied with regulatory and statutory requirements during a period of three years, namely 1997 to 1999 .

- Make recommendations regarding the improvement of local statutory and regulatory disclosure requirements, based on the history of compliance with local statutory and regulatory reporting requirements, as revealed by this research project, as well as with the requirements of IAS 34 and AC 127.

\section{$3 \quad$ Research methodology}

Fifty listed companies were selected for the years under review. The companies were selected from the Financial Mail's (1997-1999) "top industrial companies". They were selected independently for each of the years under review on the basis of total assets, market capitalisation, net profit and turnover. As a point of departure, the total asset figure was used as the dominant category. An average for each of total assets, market

Sixty-four percent of the companies originally selected in the first of the three years under consideration (1997) were selected again in the subsequent two years on the basis of their ranking. Seven companies were selected in two of the years, leaving 11 companies that were selected once only (see Annexure A). This distribution provides a fairly stable population for the interpretation of the results of the survey. The fact that some of these companies may belong to the same group of companies and that this relationship could distort compliance with the requirements was not discounted in this study. Each company was viewed as a stand-alone reporting entity. 
The fact that the same companies were not used in each consecutive year could be perceived to have an impact on comparability. However, because all the companies in the original population had to comply with the statutory, regulatory and other requirements, this reservation is not considered to present a problem in respect of identifying trends in the results of the research.

For the purposes of the study, the following disclosure requirements were selected from the three available sources:

- $\quad$ All disclosure requirements contained in IAS 34 and AC 127 were identified and subjected to testing for compliance.

- $\quad$ All disclosure requirements contained in the Companies Act and its Schedule 4 (statutory requirements) were selected and subjected to testing.

- In the JSE Listing Requirements (regulatory requirements), all the disclosure requirements relating to supplementary information were selected and subjected to testing. However, with regard to the information to be disclosed in respect of the income statement and balance sheet, selection and testing for compliance were limited to those disclosure requirements which, in the researchers' opinion, bore the greatest risk of not being adhered to.

\section{$4 \quad$ Compliance with the relevant accounting standards}

Nineteen reporting requirements, covering the disclosure requirements dealt with in IAS 34 and AC 127, were selected. As a result of fact that IAS 1 (IASC 1997c) (AC 101 (SAICA 1998a) in South Africa) was implemented for the first time in South Africa for annual financial periods commencing on 1 July 1999, it was decided not to investigate the content of condensed financial statements. Instead, the survey merely investigated whether the required components of interim financial reports were presented. The reporting issues identified for the purposes of the survey are listed in table 1 in 4.1 below.

\subsection{Comparison of disclosure requirements in accounting standards with local statutory and regulatory requirements}

Having identified the 19 disclosure requirements that are contained in IAS 34 and AC 127 and listed below, these requirements were compared with the local statutory and regulatory requirements. Where a corresponding requirement is identified, it is indicated in table 1 by reference to the appropriate document. Where no corresponding requirement can be identified, it is indicated by means of a cross. It should 
be noted that the local regulatory requirements are requirements that are applicable over and above the statutory requirements (see table 1). Statutory requirements serve as a point of departure when dealing with the regulatory requirements (JSE Listing Requirements, Companies Act Schedule 4) and are deemed to already have been met

In most cases this comparison was straightforward, but some of the individual requirements of the accounting standards were not specifically required by the statutory and regulatory requirements. Where a requirement contained in the accounting standards is not explicitly required in the statutory or regulatory documentation, but may be covered by some of the generic requirements in these documents, such requirement is elucidated in a note.

The following key indicates the source of the requirements dealt with in table 1:

SF: Schedule 4 of the Companies Act, with an indication of the paragraph number.

JR: A JSE listing requirement, with an indication of the section number.

Table 1: Comparison of relevant disclosure requirements in accounting standards with local statutory and regulatory requirements

\begin{tabular}{|c|c|c|c|c|}
\hline No & $\begin{array}{l}\text { Reporting issues - accounting } \\
\text { standards }\end{array}$ & Notes & $\begin{array}{c}\text { Statutory } \\
\text { requirements }\end{array}$ & $\begin{array}{c}\text { Regulatory } \\
\text { require- } \\
\text { ments }\end{array}$ \\
\hline & Balance sheet & & & \\
\hline \multirow[t]{2}{*}{1} & $\begin{array}{l}\text { Condensed balance sheet presented } \\
\text { (AC 127.09(a); IAS 34.8(a)). }\end{array}$ & & SF 76(2) & JR 8.46 \\
\hline & Income statement & & & \\
\hline 2 & $\begin{array}{l}\text { Condensed income statement presented } \\
\text { (AC 127.09(b); IAS 34.8(b)). }\end{array}$ & & SF 76(1) & JR 8.45 \\
\hline \multirow[t]{2}{*}{3} & $\begin{array}{l}\text { Basic and diluted earnings per share stated } \\
\text { on the face of the income statement } \\
\text { (AC 127.12; IAS 34.11). }\end{array}$ & 1 & SF 76(1)(h) & JR 8.45 \\
\hline & Statement of changes in equity & & & \\
\hline \multirow[t]{2}{*}{4} & $\begin{array}{l}\text { Condensed statement of changes in equity } \\
\text { presented (AC 127.09(c); IAS 34.8(c)). }\end{array}$ & 2 & $x$ & $x$ \\
\hline & Cash-flow statement & & & \\
\hline 5 & $\begin{array}{l}\text { Condensed cash-flow statement presented } \\
\text { (AC 127.09(d); IAS 34.8(d)). }\end{array}$ & 3 & SF 77 & $x$ \\
\hline
\end{tabular}


Table 1 (continued)

\begin{tabular}{|c|c|c|c|c|}
\hline No & $\begin{array}{l}\text { Reporting issues - accounting } \\
\text { standards }\end{array}$ & Notes & \begin{tabular}{c|} 
Statutory \\
requirements
\end{tabular} & $\begin{array}{l}\text { Regulatory } \\
\text { require- } \\
\text { ments }\end{array}$ \\
\hline & Comparatives & & & \\
\hline \multirow[t]{2}{*}{6} & 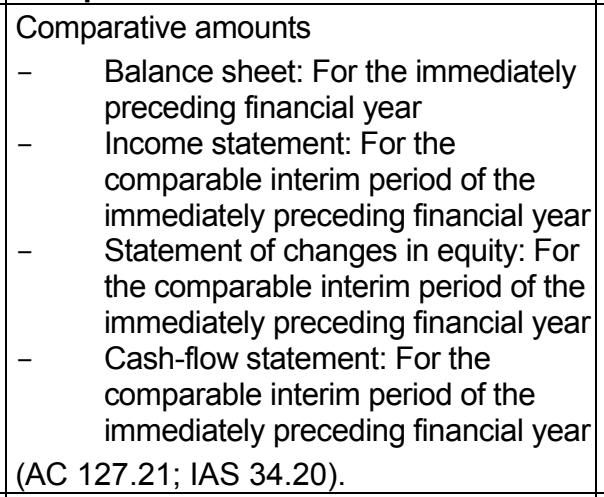 & 4 & SF74(3) & JR $8.45, .46$ \\
\hline & Note disclosure & & & \\
\hline 7 & $\begin{array}{l}\text { Statement on accounting policies and } \\
\text { methods of computation in the body of the } \\
\text { report (AC 127.17(a); IAS 34.16(a)). }\end{array}$ & 5 & $x$ & $x$ \\
\hline 8 & $\begin{array}{l}\text { Description of the nature and effect of } \\
\text { changes in accounting policies and } \\
\text { methods of computation, if applicable (AC } \\
\text { 127.17(a); IAS 34.16(a)). }\end{array}$ & & SF 79 & $8.45, .46$ \\
\hline 9 & $\begin{array}{l}\text { Explanatory comments regarding } \\
\text { seasonality or cyclicality of interim } \\
\text { operations (AC 127.17(b); IAS } 34.16(\mathrm{~b})) \text {. }\end{array}$ & 5 & $x$ & $x$ \\
\hline 10 & $\begin{array}{l}\text { Disclosure of items that are unusual, } \\
\text { because of their nature, size or incidence } \\
\text { (AC 127.17(c); IAS 34.16(c)). }\end{array}$ & 5 & $x$ & $x$ \\
\hline 11 & $\begin{array}{l}\text { Nature and amounts of changes in } \\
\text { estimates (AC 127.17(d); IAS } 34.16(d)) \text {. }\end{array}$ & 5 & $x$ & $x$ \\
\hline 12 & $\begin{array}{l}\text { Issuance, repurchases and repayments of } \\
\text { debt securities (AC 127.17(e); IAS } \\
34.16(\mathrm{e}) \text { ). }\end{array}$ & 5 & $x$ & $x$ \\
\hline 13 & $\begin{array}{l}\text { Issuance, repurchases and repayments of } \\
\text { equity securities (AC 127.17(e); IAS } \\
34.16(\mathrm{e}) \text { ). }\end{array}$ & 5 & $x$ & $X$ \\
\hline 14 & $\begin{array}{l}\text { Dividends paid (in aggregate or per } \\
\text { share) should be stated, separately for } \\
\text { ordinary shares and other shares (AC } \\
127.17(f) ; \text { IAS } 34.16(f)) .\end{array}$ & & SF 76(1)(g) & JR 8.45 \\
\hline 15 & $\begin{array}{l}\text { Segment revenue and segment results for } \\
\text { business segments or geographical } \\
\text { segments, depending on the selected } \\
\text { primary basis of segment reporting } \\
\text { (AC } 127.17(\mathrm{~g}) \text {; IAS } 34.16(\mathrm{~g}) \text { ). }\end{array}$ & 5 & $x$ & $x$ \\
\hline
\end{tabular}


Table 1 (continued)

\begin{tabular}{|c|l|c|c|c|}
\hline No & $\begin{array}{l}\text { Reporting issues - accounting } \\
\text { standards }\end{array}$ & Notes & $\begin{array}{c}\text { Statutory } \\
\text { requirements }\end{array}$ & $\begin{array}{c}\text { Regulatory } \\
\text { require- } \\
\text { ments }\end{array}$ \\
\hline 16 & $\begin{array}{l}\text { Material events subsequent to end of } \\
\text { interim period and not presented in interim } \\
\text { financial statements (AC 127.17(h); IAS } \\
34.16(\mathrm{~h}) \text { ). }\end{array}$ & 5 & $\mathrm{X}$ & $\mathrm{X}$ \\
\hline 17 & $\begin{array}{l}\text { The effect of changes in the composition of } \\
\text { the enterprise during the interim period } \\
\text { (AC 127.17(i); IAS 34.16(i). }\end{array}$ & SF 78 & $\mathrm{JR} 8.45, .46$ \\
\hline 18 & $\begin{array}{l}\text { Changes in contingent liabilities or } \\
\text { contingent assets since the last annual } \\
\text { balance sheet date (AC 127.17(j); } \\
\text { IAS 34.16(j)). }\end{array}$ & SF 78 & JR8.47(d) \\
\hline 19 & $\begin{array}{l}\text { Narrative information regarding the } \\
\text { performance of the enterprise since the last } \\
\text { reporting date (AC 127.16; IAS 34.15). }\end{array}$ & SF 74(2) & JR 8.45,.46 \\
\hline
\end{tabular}

\section{Notes to Table 1}

1. In terms of the statutory requirements, earnings per share should be disclosed, but these requirements make no reference to basic or diluted earnings per share. This may be attributable to the fact that the statutory requirements were last updated in 1992 and at that stage AC 104 (SAICA 1998b) (IAS 33 (IASC 1997a)) had not yet been revised to include these new terms. However, the term "earnings per share" could be interpreted to include both these terms. The regulatory requirements include, by implication, the earnings per share disclosure, because it forms part of the statutory requirements.

2. The prescribed regulatory and statutory requirements only deal with the balance sheet, income statement and supplementary information, while the accounting standard on interim reporting also requires a statement of changes in equity (SAICA 1998c). The fact that the statement of changes in equity is not required by the regulatory and statutory requirements means that these requirements could be outdated (Nieuwoudt \& Koen 1999:195).

3. The statutory requirement in respect of cash flow refers to "sufficient information on the cash position of the company". This phrase is open to interpretation and subjectivity and, only if it is interpreted very broadly, could include the cash flow statement as required by IAS 34 and AC 127 . The regulatory requirements include the cash flow disclosure by implication, because it forms part of the statutory requirements. In this study it was assumed that the provision of a cash flow statement would result in compliance with the statutory requirement. 
4. The statutory requirements, and therefore by implication also the regulatory requirements, require comparative information, but this requirement is described in much broader terms and also includes disclosure of the corresponding audited amounts for the most recently completed financial period. The accounting standards are very specific in this regard and list the comparative period to be disclosed for each prescribed component of the interim financial statements. In contrast to the statutory requirements, the standards only require the comparative balance sheet as at the end of the preceding financial year in the case of a condensed balance sheet.

5. In summary, SF 74(2), 76(1)(i), 76(2)(g) and 78 require any other matters or information that are material to the appreciation of the financial position and results of the operations of the company. The disclosure requirements in issues 7,9 to 13,15 and 16, as identified in the accounting standards, could, if interpreted very broadly, be included under the general explanatory disclosures required by the statutory requirements mentioned above.

\subsection{Summary of the results of a comparison of disclosure requirements in accounting standards with the statutory and regulatory requirements}

In the case of only one reporting issue (no. 4 on the statement of changes in equity), the statutory and regulatory requirements do not contain anything that can be related to the specific disclosure requirement in the accounting standard. The fairly low compliance in respect of this issue in table 2, but a major improvement in 1999, could indicate that detail compliance with AC 127 is improving where requirements are exact and require little judgement that could lead to subjectivity.

In the case of eight reporting issues identified in the accounting standard, general provisos in the statutory and regulatory requirements may address these issues, but this will depend on the judgement of the preparers. In the case of the first one, i.e. issue 7, a major improvement in compliance in 1999 could indicate that detail compliance with AC 127 is improving where requirements are exact and require little judgement, which could lead to subjectivity.

In the case of the remainder of the above eight reporting issues, namely 9 , $10,11,12,13,15$ and 16 , disclosure of the information required is either subject to the judgement of management or (as can be seen from the corresponding reporting issues in table 2) the information contained in the interim reports as such is not sufficient to eliminate uncertainties. 


\subsection{Adherence to accounting standards}

As mentioned earlier, nineteen reporting requirements were identified that cover the disclosure requirements dealt with in IAS 34 and AC 127 and therefore form part of the survey. These reporting issues are measurable in terms of the information available in the interim financial reports selected. The prescribed contents of condensed components of the financial statements were not tested in the survey, because IAS 1 (IASC 1997c) and AC 101 (SAICA 1998a) only became effective for periods commencing on 1 July 1998 and 1 July 1999 respectively. Consequently, some companies in the 1999 financial year (namely those with interim periods ending on 31 December 1999) may have complied with these content requirements while the majority would not have complied, because their interim periods did not commence on or after 1 July 1999. As a result, it was decided to merely investigate whether companies supplied these components of the financial statements in their interim financial reports. This decision facilitated greater comparability from year to year.

\section{Results of the surveys}

The results are divided into two categories, namely those that could be established with certainty (see table 2 ) and those that could not, as a result of a lack of information (see table 3).

Table 2: Percentage of adherence to accounting standards

\begin{tabular}{|c|c|c|c|c|c|}
\hline No & Reporting issues & Notes & 1999 & 1998 & 1997 \\
\hline 1 & Condensed balance sheet presented & & $100 \%$ & $100 \%$ & $100 \%$ \\
\hline 2 & Condensed income statement presented & & $100 \%$ & $100 \%$ & $100 \%$ \\
\hline 3 & $\begin{array}{l}\text { Basic and diluted earnings per share stated on } \\
\text { the face of the income statement }\end{array}$ & & $92 \%$ & $92 \%$ & $94 \%$ \\
\hline 4 & $\begin{array}{l}\text { Condensed statement of changes in equity } \\
\text { presented }\end{array}$ & 1 & $48 \%$ & $6 \%$ & $0 \%$ \\
\hline 5 & Condensed cash flow statement presented & & $96 \%$ & $84 \%$ & $94 \%$ \\
\hline 6 & 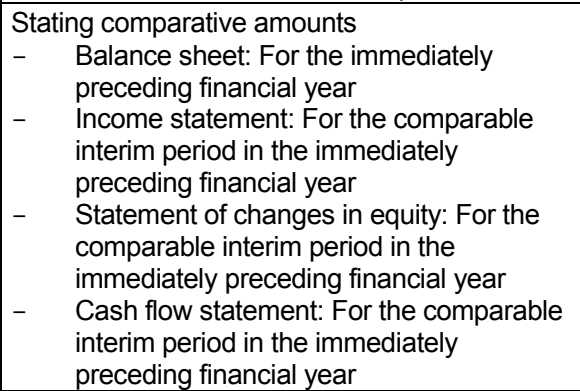 & 1 & $\begin{array}{l}100 \% \\
100 \% \\
36 \% \\
96 \%\end{array}$ & $\begin{array}{l}100 \% \\
100 \%\end{array}$ & $\begin{array}{l}100 \% \\
100 \%\end{array}$ \\
\hline 7 & $\begin{array}{l}\text { Statement on accounting policies and methods } \\
\text { of computation in the body of the report }\end{array}$ & 2 & $52 \%$ & $16 \%$ & $24 \%$ \\
\hline 8 & $\begin{array}{l}\text { Description of the nature and effect of changes } \\
\text { in accounting policies and methods of } \\
\text { computation }\end{array}$ & & $100 \%$ & $100 \%$ & $88 \%$ \\
\hline
\end{tabular}


Table 2 (continued)

\begin{tabular}{|l|l|c|c|c|c|}
\hline No & Reporting issues & Notes & $\mathbf{1 9 9 9}$ & $\mathbf{1 9 9 8}$ & $\mathbf{1 9 9 7}$ \\
\hline & $\begin{array}{l}\text { Issues } 9 \text { to } 13 \text { and 15 to 18 (see table 3) } \\
\text { Issue 14 (see table 4, requirement 10) }\end{array}$ & & & & \\
\hline 19 & $\begin{array}{l}\text { Narrative information regarding the performance } \\
\text { of the enterprise since the last reporting date }\end{array}$ & & $100 \%$ & $98 \%$ & $100 \%$ \\
\hline
\end{tabular}

Table 3: Number of companies that adhere to the relevant accounting standards (in each case, out of a total of 50 companies)

\begin{tabular}{|c|c|c|c|c|c|}
\hline No & Reporting issues & Notes & 1999 & 1998 & 1997 \\
\hline 9 & $\begin{array}{l}\text { Explanatory comments regarding seasonality } \\
\text { or cyclicality of interim operations } \\
-\quad \text { Adhere } \\
-\quad \text { Uncertain }\end{array}$ & 3 & $\begin{array}{l}14 \\
36 \\
\end{array}$ & $\begin{array}{c}7 \\
43 \\
\end{array}$ & $\begin{array}{l}15 \\
35\end{array}$ \\
\hline 10 & $\begin{array}{l}\text { Disclosure of items that are unusual, because } \\
\text { of their nature, size or incidence } \\
-\quad \text { Adhere } \\
-\quad \text { Non-adherence } \\
-\quad \text { Uncertain } \\
\end{array}$ & 4 & $\begin{array}{c}0 \\
27 \\
23\end{array}$ & $\begin{array}{c}1 \\
35 \\
14\end{array}$ & $\begin{array}{c}1 \\
28 \\
21\end{array}$ \\
\hline 11 & Nature and amounts of changes in estimates & 5 & 3 & 0 & $\begin{array}{c}\text { Not } \\
\text { tested }\end{array}$ \\
\hline 12 & $\begin{array}{l}\text { Issuance, repurchases and repayments of } \\
\text { debt securities } \\
-\quad \text { Adhere } \\
-\quad \text { Non-adherence } \\
-\quad \text { Uncertain } \\
-\quad \text { Not applicable } \\
\end{array}$ & & $\begin{array}{c}3 \\
2 \\
44 \\
1 \\
\end{array}$ & $\begin{array}{c}2 \\
3 \\
42 \\
3 \\
\end{array}$ & $\begin{array}{c}1 \\
6 \\
40 \\
3 \\
\end{array}$ \\
\hline 13 & $\begin{array}{l}\text { Issuance, repurchases and repayments of } \\
\text { equity securities } \\
-\quad \text { Adhere } \\
-\quad \text { Non-adherence }\end{array}$ & 6 & $\begin{array}{l}28 \\
22 \\
\end{array}$ & $\begin{array}{c}\text { Not } \\
\text { Tested }\end{array}$ & $\begin{array}{c}\text { Not } \\
\text { tested }\end{array}$ \\
\hline 14 & (See table 4, requirement 10 ) & & & & \\
\hline 15 & $\begin{array}{l}\text { Segment revenue and segment results for } \\
\text { business segments or geographical segments } \\
-\quad \text { Adhere } \\
-\quad \text { Non-adherence } \\
-\quad \text { Uncertain }\end{array}$ & & $\begin{array}{l}13 \\
22 \\
15\end{array}$ & $\begin{array}{l}12 \\
23 \\
15\end{array}$ & $\begin{array}{l}13 \\
24 \\
13\end{array}$ \\
\hline 16 & $\begin{array}{l}\text { Events subsequent to the end of interim period } \\
-\quad \text { Adherence } \\
-\quad \text { Uncertain }\end{array}$ & & $\begin{array}{l}20 \\
30 \\
\end{array}$ & $\begin{array}{l}12 \\
38 \\
\end{array}$ & $\begin{array}{l}22 \\
28 \\
\end{array}$ \\
\hline 17 & $\begin{array}{l}\text { The effect of changes in the composition of the } \\
\text { enterprise during the interim period } \\
-\quad \text { Adherence } \\
-\quad \text { Non-adherence } \\
-\quad \text { Uncertain }\end{array}$ & 7 & $\begin{array}{c}20 \\
4 \\
26\end{array}$ & $\begin{array}{c}24 \\
0 \\
26\end{array}$ & $\begin{array}{c}29 \\
1 \\
20 \\
\end{array}$ \\
\hline 18 & $\begin{array}{l}\text { Changes in contingent liabilities or contingent } \\
\text { assets since the last annual balance sheet } \\
\text { date } \\
-\quad \text { Adherence } \\
-\quad \text { Non-adherence } \\
-\quad \text { Uncertain } \\
\end{array}$ & 8 & $\begin{array}{c}25 \\
3 \\
22\end{array}$ & $\begin{array}{c}26 \\
2 \\
22\end{array}$ & $\begin{array}{l}14 \\
12 \\
24\end{array}$ \\
\hline
\end{tabular}




\section{Notes to Tables 2 and 3}

Comment on table 2 is provided in cases in which adherence is below $80 \%$.

1. The fact that a condensed statement of changes in equity, in terms of IAS 34 and AC 127 (IAS 1998, SAICA 1998c), is not provided by the majority of companies in the research population, can probably be attributed to the fact that a statement of changes in equity is only required in South Africa for financial periods commencing on 1 July 1999, when AC 101 (the South African equivalent of IAS 1) became effective. This is also the date on which AC 127 became effective (AC 127 par. 47).

2. An important implication of one of the qualitative characteristics of financial statements, namely comparability, is that users of financial statements should be informed about the accounting policies adopted by an entity (SAICA 1990, par. 40). IAS 34, par. 16 (compare AC 127, par. 17) makes it clear that a year-todate basis should be used to measure and recognise financial information for interim reporting purposes. If a company's interim financial report complies with AC 127 (compare IAS 34), this fact should be disclosed in order to make users aware of the principles applied in the preparation of the interim financial report without enumerating the principles (compare IASC 1997d, par. 21-22; IASC 1998, par. 19, SAICA 1998c, par. 20).

Only twenty-six companies (1998:8) stated the relevant information on compliance with AC 127 in the interim financial report itself. However, twenty-eight companies (1998:12) included a statement, either in the interim financial report or as part of the public announcement regarding the audit review, that the interim financial statements comply with the Statements of Generally Accepted Accounting Practice (GAAP), thereby implying that the year-to-date method was used.

Comment on table 3 is provided in cases in which valid reasons for noncompliance could be identified, because the uncertainties under these items complicated interpretation.

3. A total of 14 companies (1998:7) submitted explanatory comments on the seasonality or cyclicality of their interim operations. Because only interim reports were considered, it was not possible to determine whether the remaining 36 companies (1998:43) should have presented the information or whether the disclosure requirement was not applicable.

4. Items of an "unusual" nature require special disclosure, because they are particularly relevant for users of financial statements to 
understand and make projections about the financial position and performance of the entity concerned (IASC 1996c, par. 38). "Unusual" items include income and expenses from ordinary activities that are normally disclosable separately, extraordinary items, business combinations, correction of fundamental errors, etc. The disclosure of these items in annual financial statements is required by GAAP, and the need for the information applies equally to interim financial reports. Although the specific requirement contained in IAS 34, par. 16(c) (AC 127, par. 17(c)) addresses the effect of unusual items on various items in the financial statements, namely assets, liabilities, equity, net income and cash flows, the survey was focused on only separately disclosable items within profit or loss from ordinary activities, as discussed in accounting opinion AC 307 of SAICA (SAICA 1996:1-3).

Of the 27 (1997:36) companies that reported items that are disclosable because of their nature, size or incidence, 25 (1997:35) companies appear to be ignorant of the latest developments in GAAP in South Africa on this issue (see AC 307 - SAICA 1996). They did, however, comply in broad terms with the requirements of IAS 34, par. 16 (c) (AC 127 par, 17(c)).

5. Unless the companies indicated whether they did have changes in estimates, it was not possible to comment on whether they had adhered to this requirement of IAS 34 and AC 127. If the three companies that indicated that they had had changes in estimates were indeed the only ones to have had such changes, compliance would have been $100 \%$.

6. The disclosure of movements between the opening and closing balances of equity securities is as significant for interim financial reporting purposes as it is for annual financial statement purposes. IAS 34, par. 16(c) and AC 127, par. 9(c) require the inclusion in the interim financial report of a condensed statement showing either all changes in equity or changes in equity other than those arising from capital transactions with owners and distributions to owners. As very few companies presented a statement of changes in equity (see requirement 6 in table 2), it is to be expected that relatively few companies comply with this requirement. The matter is further complicated by the fact that, until 1 July 1999 when the amended section 85 of the Companies Act came into effect, companies in South Africa were not allowed to buy back their own shares unless this action had been sanctioned by the court (Companies Act, Section 84).

7. The volume of uncertainties under this requirement made comment difficult. It would, however, appear as if companies are reluctant to provide this information, because fairly low compliance figures were also experienced in respect of requirements 18 in table 4 and 25 in table 5. 
8. A total of 28 (1998:28) companies disclosed contingent liabilities in terms of Schedule 4 of the Companies Act (see requirement 21 in table 5). Twenty-five (1998:26) of these companies provided information on the changes in contingent liabilities or contingent assets.

\subsection{Conclusion - International and local accounting standards}

As could be expected, as a result of the implementation of AC 127 (IAS 34) in South Africa, compliance with virtually all reporting issues contained in the accounting standards either reflect increases or remained constant over the three-year period under review. By stating that the interim financial report complies with AC 127 (IAS 34), most of the uncertainties regarding the absence of certain information (see table 3 ) will be dispelled. The user will know that, in the absence of any information, the requirement does not apply. Preparers of interim financial reports should pay attention to the following matters:

- A statement of changes in equity should be provided.
- The fact that the interim financial report complies with GAAP and
with AC 127 should be stated.

By giving the above information, compliance with local and international accounting standards will improve considerably, making the information contained in the interim financial reports more useful and reliable for the users of these reports.

\section{Compliance by companies with local statutory and regulatory disclosure requirements}

Section 303 of the Companies Act, No. 61 of 1973 (as amended) requires every public company that has share capital (other than a wholly owned subsidiary) to issue a half-yearly interim financial report. This statutory report should be issued not later than three months after the end of the first period of six months of the company's financial year. The interim financial report is required to fairly present the business and operations of the company or, in the case of a parent company, that of the group. The interim financial report should deal with the matters set out in paragraphs 73, 74 and 76-79 of Schedule 4 of the Companies Act (statutory disclosure requirements). Furthermore, section 8 of the JSE Listing Requirements identifies supplementary disclosure requirements for listed companies (regulatory disclosure requirements). Both the statutory and regulatory requirements relate primarily to balance sheet, income statement and supplementary note disclosures, with little emphasis on cash flow information. The statement of changes in equity is a new development (SAICA 1998a, c) and therefore (presumably) does not from part of the above-mentioned requirements. 
The following key indicates the source of the requirements dealt with in section 5 (tables 4 and 5 ) of this report:

CS: A section of the Companies Act, with an indication of the section number.

SF: Schedule 4 of the Companies Act, with an indication of the paragraph number.

JR: A JSE listing requirement, with an indication of the section number.

\section{Results of the surveys}

Table 4: Percentage of compliance with local statutory and regulatory requirements

\begin{tabular}{|c|c|c|c|c|c|}
\hline No & Requirement tested & Notes & 1999 & 1998 & 1997 \\
\hline & General disclosures & & & & \\
\hline 1 & $\begin{array}{l}\text { The interim financial report should cover a six-month } \\
\text { period (CS 303) }\end{array}$ & & $100 \%$ & $100 \%$ & $100 \%$ \\
\hline 2 & $\begin{array}{l}\text { The interim financial report should be issued within } \\
\text { three months after the end of the six-month period } \\
\text { covered in the report (CS 303) }\end{array}$ & & $96 \%$ & $100 \%$ & $98 \%$ \\
\hline 3 & $\begin{array}{l}\text { Interim financial reports should be approved by the } \\
\text { directors of the company and signed on their behalf } \\
\text { by two directors (CS } 305(3) \text { ) }\end{array}$ & $1, \mathrm{~A}$ & $10 \%$ & $8 \%$ & $12 \%$ \\
\hline 4 & $\begin{array}{l}\text { Amounts in respect of the immediately preceding } \\
\text { corresponding interim period and the corresponding } \\
\text { audited amounts in respect of the most recent } \\
\text { financial period should be stated (SF } 74(3)) \\
-\quad \text { Income statement } \\
-\quad \text { Balance sheet }\end{array}$ & & $\begin{array}{l}98 \% \\
96 \%\end{array}$ & $\begin{array}{l}100 \% \\
94 \%\end{array}$ & $\begin{array}{l}100 \% \\
98 \%\end{array}$ \\
\hline 5 & $\begin{array}{l}\text { If applicable, turnover should be disclosed } \\
\text { (SF 76(1)(a)) }\end{array}$ & & $100 \%$ & $100 \%$ & $100 \%$ \\
\hline 6 & Depreciation should be disclosed (JR 8. 45 (c)) & $\mathrm{B}$ & $82 \%$ & $88 \%$ & $88 \%$ \\
\hline 7 & Interest paid should be disclosed (JR 8. 45 (d)) & 2 & $66 \%$ & $58 \%$ & $56 \%$ \\
\hline 8 & $\begin{array}{l}\text { Net income before interest paid and taxation should } \\
\text { be disclosed as a separate line item in the income } \\
\text { statement (JR 8. 45(e)) }\end{array}$ & 2 & $12 \%$ & $14 \%$ & $14 \%$ \\
\hline 9 & $\begin{array}{l}\text { Net income attributable to ordinary shareholders } \\
\text { should be disclosed (SF 76(1)(f)) }\end{array}$ & & $100 \%$ & $100 \%$ & $100 \%$ \\
\hline 10 & $\begin{array}{ll}\text { Dividends per share should be disclosed } \\
\text { (SF 76(2)(d)) } \\
-\quad \text { Ordinary shares } \\
-\quad \text { Preference shares } \\
\end{array}$ & 3 & $\begin{array}{l}98 \% \\
71 \% \\
\end{array}$ & $\begin{array}{l}96 \% \\
44 \% \\
\end{array}$ & $\begin{array}{l}100 \% \\
38 \%\end{array}$ \\
\hline \multirow[t]{2}{*}{11} & $\begin{array}{l}\text { Earnings per share should be disclosed } \\
(\text { SF } 76(1((\mathrm{~h}))\end{array}$ & & $96 \%$ & $92 \%$ & $96 \%$ \\
\hline & Balance sheet & & & & \\
\hline 12 & $\begin{array}{l}\text { The balance sheet should disclose separately non- } \\
\text { interest-bearing debt (SF 76(2)(c)) and interest- } \\
\text { bearing debt (SF 76(2)(d)) }\end{array}$ & 4 & $40 \%$ & $60 \%$ & $66 \%$ \\
\hline 13 & $\begin{array}{l}\text { Net asset value per share should be disclosed } \\
\text { (SF 76(2)(e)) }\end{array}$ & C & $86 \%$ & $84 \%$ & $90 \%$ \\
\hline
\end{tabular}


Table 4 (continued

\begin{tabular}{|c|c|c|c|c|c|}
\hline No & Requirement tested & Notes & 1999 & 1998 & 1997 \\
\hline & Supplementary information & & & & \\
\hline 14 & $\begin{array}{l}\text { The interim financial report should include sufficient } \\
\text { information on the cash position of the company } \\
\text { (SF 77) }\end{array}$ & & $96 \%$ & $88 \%$ & $94 \%$ \\
\hline 15 & $\begin{array}{l}\text { Information regarding capital commitments should } \\
\text { be provided (SF } 78 \text { and JR 8. } 47(\mathrm{~b}) \text { ) }\end{array}$ & 5 & $78 \%$ & $82 \%$ & $88 \%$ \\
\hline 16 & $\begin{array}{l}\text { Capital expenditure for the current period should be } \\
\text { stated (JR 8.47(a)) }\end{array}$ & 6 & $72 \%$ & $68 \%$ & $64 \%$ \\
\hline 17 & $\begin{array}{l}\text { An exceptional increase in borrowings during the } \\
\text { period under review and the effect of such } \\
\text { borrowings on earnings per share should be stated } \\
\text { (JR 8. } 47(\mathrm{~g}) \text { ) } \\
\text { (Number of companies that disclosed the information } \\
\text { divided by the number of companies that had an } \\
\text { exceptional increase in borrowings) }\end{array}$ & $7, \mathrm{D}$ & $(0 / 2)$ & $0 \%$ & $12 \%$ \\
\hline 18 & $\begin{array}{l}\text { Changes in the relative holding in any subsidiary } \\
\text { should be stated (SF 78) } \\
\text { (Number of companies that disclosed the information } \\
\text { divided by the number of companies that had an } \\
\text { exceptional change in relative holdings) }\end{array}$ & 8 & $\begin{array}{l}70 \% \\
(14 / 20)\end{array}$ & $\begin{array}{r}63 \% \\
(19 / 30)\end{array}$ & $\begin{array}{l}64 \% \\
(14 / 22)\end{array}$ \\
\hline
\end{tabular}

Table 5: Number of companies that comply with local statutory and regulatory requirements (in each case, out of a total of 50 companies)

\begin{tabular}{|c|c|c|c|c|c|}
\hline No & Balance sheet & Notes & 1999 & 1998 & 1997 \\
\hline 19 & $\begin{array}{ll}\text { Disclosure of preference share capital (JR 8. 46(f)) } \\
-\quad \text { Disclose preference share capital } \\
-\quad \text { Do not disclose preference share capital } \\
\quad \text { although preference dividends were declared } \\
-\quad \text { Only ordinary share capital in issue } \\
-\quad \text { Uncertain }\end{array}$ & $9, \mathrm{E}$ & $\begin{array}{l}7 \\
0 \\
14 \\
29\end{array}$ & $\begin{array}{c}9 \\
0 \\
15 \\
26\end{array}$ & $\begin{array}{c}12 \\
1 \\
15 \\
22\end{array}$ \\
\hline & Supplementary information & & & & \\
\hline 20 & $\begin{array}{l}\text { Any comments on any facts or circumstances } \\
\text { relevant to the financial position of the company, } \\
\text { and where applicable, of the group, necessary for a } \\
\text { better assessment of the information given, should } \\
\text { be stated (SF 78) } \\
\text { - } \quad \text { Disclosed } \\
-\quad \text { Uncertain }\end{array}$ & 10 & $\begin{array}{l}32 \\
18 \\
\end{array}$ & $\begin{array}{l}26 \\
24 \\
\end{array}$ & $\begin{array}{l}22 \\
28 \\
\end{array}$ \\
\hline 21 & $\begin{array}{l}\text { Information regarding contingencies should be } \\
\text { stated (SF } 78 \text { and JR } 8.47(\mathrm{~d})) \\
-\quad \text { Disclosed } \\
-\quad \text { Uncertain } \\
\end{array}$ & 11 & $\begin{array}{l}28 \\
22 \\
\end{array}$ & $\begin{array}{l}28 \\
22 \\
\end{array}$ & $\begin{array}{l}26 \\
24 \\
\end{array}$ \\
\hline 22 & $\begin{array}{l}\text { The following commitments should be stated: } \\
(\mathrm{JR} \text { 8. } 47(\mathrm{c})) \\
-\quad \text { Disclose finance lease commitments } \\
-\quad \text { Uncertain } \\
\quad \text { AND } \\
-\quad \text { Disclose operating lease commitments } \\
-\quad \text { Uncertain }\end{array}$ & $\begin{array}{l}12 \\
F \\
12\end{array}$ & $\begin{array}{c}1 \\
49 \\
11 \\
39 \\
\end{array}$ & $\begin{array}{c}1 \\
49 \\
7 \\
73 \\
4\end{array}$ & $\begin{array}{c}0 \\
50 \\
\\
5 \\
45\end{array}$ \\
\hline 23 & $\begin{array}{ll}\text { Interest capitalised should be stated (JR } 8.47(\mathrm{e})) \\
-\quad & \text { Disclosed } \\
- & \text { Uncertain }\end{array}$ & $13, \mathrm{G}$ & $\begin{array}{c}9 \\
41 \\
\end{array}$ & $\begin{array}{c}7 \\
43 \\
\end{array}$ & $\begin{array}{c}8 \\
42 \\
\end{array}$ \\
\hline
\end{tabular}


Table 5 (continued)

\begin{tabular}{|l|l|c|c|c|c|}
\hline No & Requirement tested & Notes & $\mathbf{1 9 9 9}$ & $\mathbf{1 9 9 8}$ & $\mathbf{1 9 9 7}$ \\
\hline 24 & If applicable and material, full disclosure of all & & & & \\
& borrowings and off-balance sheet borrowings should \\
& be included (JR 8. 47(f)) & & & & \\
& $-\quad$ Disclosed & $14, \mathrm{H}$ & 1 & 0 & 4 \\
& $-\quad$ Uncertain & & 49 & 50 & 46 \\
\hline 25 & Comments on acquisitions and disposals of & & & & \\
& subsidiaries should be included (SF 78) & 15 & 20 & 30 & 22 \\
& $-\quad$ Include information & & 0 & 4 & 7 \\
& $-\quad$ Not applicable & & 30 & 16 & 21 \\
\hline
\end{tabular}

\section{Notes to tables 4 and 5}

\section{General}

The requirements (indicated by number) that were tested and that revealed compliance of less than $80 \%$ in 1999 , were discussed to establish possible reasons for the non-compliance.

1. Reports are not approved and signed by two directors. In only $10 \%$ of the cases was this requirement adhered to. Noncompliance may be the result of the fact that this requirement does not appear in IAS 34 or AC 127.

2. The companies that did not fulfil this requirement stated only the net interest paid as required by Schedule 4, paragraph 76(1)(c). This disclosure differs from the JSE Listing Requirement that interest paid should be disclosed. There appears to be some confusion about the very similar, yet different, requirements contained in Schedule 4 and the JSE Listing Requirements. Consistent with this trend, most companies disclosed the line item net income before net interest paid and taxation, instead of net income before interest paid and taxation (refer to requirement 8), which points to an application of the Schedule 4 requirement together with the JSE Listing Requirements. An additional matter that could add to the confusion is the reference to "interest paid" instead of "finance costs". Interest paid could be interpreted as interest paid in cash rather than the aggregate of interest accrued and paid in cash, as could be expected in terms of the accrual basis. The preparers of financial statements may argue that this information could be obtained from the cash flow statement, although it is clearly not the intention of the requirement. IAS 34 and AC 127 respectively require this information to be disclosed, if they are read in conjunction with IAS 1.75(b), (c) and AC 101.76(b), (c).

3. The percentages for preference dividends are based on the information that appears under requirement 19 in table 5 for the companies that had issued preference shares. IAS 34.16(f) and 
AC 127.17(f) require dividends to be disclosed, either in aggregate or per share.

4. IAS 34 and AC 127, if read in conjunction with IAS 1.66(k) and AC $101.67(\mathrm{k})$, require a company to disclose non-current interest-bearing liabilities. The implication is that non-current liabilities that are not designated as interest-bearing liabilities will therefore be non-interest bearing. However, Schedule 4 does not require a company to distinguish between current and noncurrent debt. Therefore the low compliance may be the result of confusion arising from the contradictory requirements contained in the accounting standards and statutory requirements.

5. IAS 34.17(e) and AC 127.18(e) also require that information on capital commitments should be disclosed. Therefore noncompliance with the statutory and regulatory requirements implies a contravention of the relevant accounting standard.

6. IAS 34.17(d) requires disclosure of acquisitions and disposals of items of property, plant and equipment. Consequently, noncompliance with this regulatory requirement also implies a contravention of the relevant accounting standard. The trend during the period 1997 to 1999 appears to be that of a gradual increase in compliance. (Koen et al 1998-2000).

7. The companies that comply with this requirement, furnished reasons for the exceptional increase in borrowings, but did not disclose the effect on earnings per share. For the purposes of the survey, an increase of $50 \%$ or more in borrowings since the last annual balance sheet date was considered to be an exceptional increase. The survey revealed that the following number of companies had exceptional increases in borrowings: 1999:2; 1998:9; and 1997:17. This regulatory requirement is not dealt with in IAS 34 and AC 127 and this fact may have contributed to the low compliance figure.

8. The percentages are based on the information contained in requirement 25 in table 5 , where the number of companies that disclosed acquisitions and disposals of subsidiaries was determined. This disclosure requirement is also contained in IAS 34.16(i) and AC 127.17(i), and therefore the low adherence to the statutory requirement also points to non-compliance with the relevant accounting standards.

9. Section 8.46(e) of the JSE Listing Requirements clearly requires that ordinary shareholders' funds should be stated. In contrast, Schedule 4, paragraph 76(2)(b) requires that shareholders' funds should be disclosed. It could therefore be argued that uncertainty in respect of preference shares relates to a contravention of the JSE Listing Requirements. In terms of the relevant accounting standards, this distinction need not be 
supplied, but the distinction may be encountered in the condensed statement of changes in equity.

10. This statutory and regulatory requirement is also contained in IAS 34.16 and AC 127.17 and this fact may explain the increase in compliance between 1997 and 1999.

11. The statutory and regulatory requirement is also contained in IAS 34.16(j) and AC 127.17(j).

12. The outcome of the disclosure of this requirement did not make sense. It was therefore decided to scrutinise the annual financial statements of the companies under review to establish whether the requirement was applicable. It was established that most of the companies either have finance leases or operating leases or both. This means that companies do not provide the information that is required. In view of the fact that the revised AC 105 (SAICA 1999) and IAS 17 (IASC 1997e)) now require companies to disclose information on commitments in respect of operating and finance leases in their annual financial statements, future compliance with this requirement is expected to improve, because the companies will in future have the required information for interim purposes at their disposal. Note that this requirement is not contained in IAS 34 and AC 127.

13. The disclosure of interest capitalised is not contained in IAS 34 or AC 127, nevertheless the regulatory requirement appears to be a sensible disclosure, because finance costs can be eliminated from the face of the income statement by capitalising it in total.

14. This requirement is not contained in IAS 34 and AC 127.

15. Companies group their acquisition and disposal of property; plant and equipment; businesses and subsidiaries together, making it difficult, in the absence of an explanatory note, to establish whether subsidiaries were involved. IAS 34.16(i) and AC 127.17(i) also require disclosure of the effect of changes in the composition of the enterprise in the interim period, which is similar to what is required in this regard.

\subsection{Comments on statutory and regulatory requirements with reference to IAS 34 and AC 127}

The notes indicated by letters $A$ to $H$ in tables 4 and 5 refer to the statutory and regulatory requirements for which there are no explicit corresponding disclosure requirement in either IAS 34 or AC 127. Two general trends appear to come to the fore when these items are considered.

It can be concluded, firstly, that there is a large measure of compliance with requirements that are fairly easy to calculate, because the 
information is available in the trial balance on a month to month basis and would normally be calculated for annual reporting purposes - see B, $\mathrm{C}$ and $\mathrm{E}$.

Secondly, companies tend to disregard items that are not generally supplied in the annual financial statements or that have to be specifically calculated at year-end and only relate to JSE Listing Requirements - see $\mathrm{D}, \mathrm{F}, \mathrm{G}$ and $\mathrm{H}$.

Non-compliance with reporting issue 3 (also see note 1 and A) furthermore appears to indicate that directors do not take interim financial reports seriously as non-compliance represents a contravention of Section 305(3) of the Companies Act.

\subsection{Conclusion - Statutory and regulatory disclosure requirements}

In contrast to the expectation that compliance with statutory and regulatory requirements would be high, it is indeed very low. Of the twenty-five requirements that were investigated in 1999, only three requirements (1998:4) had 100\% compliance. Compliance with seven (1998:7) requirements varied between $80 \%$ and $98 \%$. For four (1998:4) requirements the compliance was between $50 \%$ and $79 \%$, and compliance in respect of a further four (1998:4) requirements was below $50 \%$. Compliance in respect of seven (1998:6) of the requirements could not be established with certainty (see table 5 ). There was neither major progress nor regression in respect of compliance with requirements in the three years under review.

The question that should be answered is: What are the reasons for the low compliance? Any one of the following could be the reason: There are too many regulations; directors pay insufficient attention to compliance; lack of policing on these matters on the part of the Registrar of Companies or the JSE Board; or companies feel that the information is outdated and of no use to the users of the interim financial statements in the light of the latest accounting standards. Another possible reason for non-compliance is that the degree of difficulty associated with extracting the interim information from the accounting records may discourage disclosure.

The fact that there are too many regulations could be linked to the existence of three different documents (four, if IAS 34 is included) that govern interim reporting.

The fact that directors pay too little attention to interim reporting is demonstrated by the very limited number of interim reports that are signed by two directors on behalf of the board of directors. 
If it were fairly easy to obtain the information required for interim reporting, disclosures would be made. However, if the information were difficult to obtain and only related to a JSE Listing Requirement or to Schedule Four, companies would tend not to provide the disclosure. In the latter two instances, better policing could solve the problem.

Whatever the reasons, the following weaknesses in reporting practices were identified:

- Information is not adequately interpreted. For example, when a company had had an exceptional increase in borrowings, the reasons for the increase were given, but the effect on earnings per share was ignored (see requirement 17, table 4).

- $\quad$ Correlation between requirements is ignored (see requirements 7, 8, 12 and 17, table 4). Interest paid relates to interest-bearing debt and an exceptional increase in borrowings and the effect thereof on earnings per share clearly relates to the distinction between interest-bearing and non-interest-bearing debt. When only net interest paid is disclosed, and borrowings are not split between interest-bearing and non-interest-bearing debt, users cannot make informed decisions. In the light of the comparatively high interest rates prevailing in South Africa, it can hardly be argued that this information is not useful.

- $\quad$ There appears to be some confusion about very similar, yet different, disclosure requirements that are contained in Schedule 4 and the JSE Listing Requirements. For example, confusion exists about the disclosure of interest paid versus net interest paid (see note 2 above) and the disclosure of shareholders' funds versus disclosure of preference share capital and ordinary shareholders' funds (see note 9 above).

\section{Overall recommendations regarding the improvement of interim financial reporting}

The following recommendations may serve to improve the quality of reporting in interim financial statements:

- Section 303 of the Companies Act states only that the interim financial statements are required to fairly present the business and operations of the company or the group. This requirement is not linked to Statements of Generally Accepted Accounting Practice (GAAP) as in the case with annual financial statements. Linking the preparation and presentation of interim financial reports to GAAP (namely AC 127) will eliminate uncertainties about the methods and principles adopted in the preparation of the reports

- The three sources of disclosure requirements for interim reporting should be aligned with one another. 
- Only additional information that is peculiar to the South African context and not dealt with in accounting standard AC 127 should be included in Schedule 4 and the JSE Listing Requirements, for example information on borrowings and interest paid as a result of the comparatively high interest rates prevailing in South Africa. Similar disclosure requirements already dealt with in the accounting standards should not be duplicated, for example dividends per share, stating of comparative amounts, earnings per share, cash flow information and contingent liabilities. This measure will also eliminate confusion where the wording of accounting standards and of statutory and regulatory requirements are inconsistent.

- The policing of compliance with disclosure requirements that are contained in laws, regulations and accounting standards should be improved.

\section{ANNEXURE A}

\section{ALPHABETICAL LIST OF COMPANIES INVOLVED IN THE SURVEY}

\begin{tabular}{|c|c|c|c|}
\hline & 1997 & 1998 & 1999 \\
\hline 1 & AECI Ltd & AECI Ltd & AECI Ltd \\
\hline 2 & African Oxygen Ltd & African Oxygen Ltd & African Oxygen Ltd \\
\hline 3 & Anglo Vaal Industrial Ltd & Anglo Vaal Industrial Ltd & Anglo Vaal Industrial Ltd \\
\hline 4 & Barlow Ltd & Barlow Ltd & Barlow Ltd \\
\hline 5 & C. G. Smith Ltd & C. G. Smith Ltd & C. G. Smith Ltd \\
\hline 6 & Edgars Stores Ltd & Edgars Stores Ltd & Edgars Stores Ltd \\
\hline 7 & Foschini Ltd & Foschini Ltd & Foschini Ltd \\
\hline 8 & $\begin{array}{l}\text { Highveld Steel \& Vanadium } \\
\text { Corporation Ltd }\end{array}$ & $\begin{array}{l}\text { Highveld Steel \& Vanadium } \\
\text { Corporation Ltd }\end{array}$ & $\begin{array}{l}\text { Highveld Steel \& Vanadium } \\
\text { Corporation Ltd }\end{array}$ \\
\hline 9 & Imperial Holdings Ltd & Imperial Holdings Ltd & Imperial Holdings Ltd \\
\hline 10 & Iscor Ltd & Iscor Ltd & Iscor Ltd \\
\hline 11 & JD Group Ltd & JD Group Ltd & JD Group Ltd \\
\hline 12 & Illovo Ltd & Illovo Ltd & Illovo Ltd \\
\hline 13 & Kersaf Investments Ltd & Kersaf Investments Ltd & Kersaf Investments Ltd \\
\hline 14 & Malbak Ltd & Malbak Ltd & Malbak Ltd \\
\hline 15 & Metro Cash and Carry Ltd & Metro Cash and Carry Ltd & Metro Cash and Carry Ltd \\
\hline 16 & Nampak Ltd & Nampak Ltd & Nampak Ltd \\
\hline 17 & Nasionale Pers Bpk & Nasionale Pers Bpk & Nasionale Pers Bpk \\
\hline 18 & Pepkor Ltd & Pepkor Ltd & Pepkor Ltd \\
\hline 19 & Pick 'n Pay Stores Ltd & Pick 'n Pay Stores Ltd & Pick 'n Pay Stores Ltd \\
\hline 20 & $\begin{array}{l}\text { Pretoria Portland Cement } \\
\text { Company Ltd }\end{array}$ & $\begin{array}{l}\text { Pretoria Portland Cement } \\
\text { Company Ltd }\end{array}$ & $\begin{array}{l}\text { Pretoria Portland Cement } \\
\text { Company Ltd }\end{array}$ \\
\hline 21 & Rembrandt Group Ltd & Rembrandt Group Ltd & Rembrandt Group Ltd \\
\hline 22 & Reunert Ltd & Reunert Ltd & Reunert Ltd \\
\hline 23 & $\begin{array}{l}\text { Safmarine and Rennies } \\
\text { Holdings Ltd }\end{array}$ & $\begin{array}{l}\text { Safmarine and Rennies } \\
\text { Holdings Ltd }\end{array}$ & $\begin{array}{l}\text { Safmarine and Rennies } \\
\text { Holdings Ltd }\end{array}$ \\
\hline 24 & Sappi Ltd & Sappi Ltd & Sappi Ltd \\
\hline
\end{tabular}




\begin{tabular}{|l|l|l|l|}
\hline & 1997 & 1998 & 1999 \\
\hline 25 & Sasol Ltd & Sasol Ltd & Sasol Ltd \\
\hline 26 & Shoprite Holdings Ltd & Shoprite Holdings Ltd & Shoprite Holdings Ltd \\
\hline 27 & $\begin{array}{l}\text { Sun International (South } \\
\text { Africa) Ltd }\end{array}$ & $\begin{array}{l}\text { Sun International (South } \\
\text { Africa) Ltd }\end{array}$ & $\begin{array}{l}\text { Sun International (South } \\
\text { Africa) Ltd }\end{array}$ \\
\hline 28 & The Bidvest Group Ltd & The Bidvest Group Ltd & The Bidvest Group Ltd \\
\hline 29 & $\begin{array}{l}\text { The South African Breweries } \\
\text { Ltd }\end{array}$ & $\begin{array}{l}\text { The South African } \\
\text { Breweries Ltd }\end{array}$ & $\begin{array}{l}\text { The South African } \\
\text { Breweries Ltd }\end{array}$ \\
\hline 30 & $\begin{array}{l}\text { The Tongaat-Hulett Group } \\
\text { Ltd }\end{array}$ & $\begin{array}{l}\text { The Tongaat-Hulett Group } \\
\text { Ltd }\end{array}$ & $\begin{array}{l}\text { The Tongaat-Hulett Group } \\
\text { Ltd }\end{array}$ \\
\hline 31 & Tiger Oates Ltd & Tiger Oates Ltd & Tiger Oates Ltd \\
\hline 32 & Wooltru Ltd & Wooltru Ltd & Wooltru Ltd \\
\hline
\end{tabular}

\begin{tabular}{|l|l|l|l|}
\hline & Selected twice & Selected twice & Selected twice \\
\hline & - & Adcock Ingram Ltd (33) & Adcock Ingram Ltd (33) \\
\hline $\begin{array}{l}\text { Anglo American Industrial } \\
\text { Corporation Ltd (33) }\end{array}$ & $\begin{array}{l}\text { Anglo American Industrial } \\
\text { Corporation Ltd (34) }\end{array}$ & - \\
\hline- & $\begin{array}{l}\text { Cadbury Schweppes (SA) } \\
\text { Ltd (35) }\end{array}$ & $\begin{array}{l}\text { Cadbury Schweppes (SA) } \\
\text { Ltd (34) }\end{array}$ \\
\hline $\begin{array}{l}\text { Del Monte Royal Foods Ltd } \\
(34)\end{array}$ & $\begin{array}{l}\text { Del Monte Royal Foods Ltd } \\
(36)\end{array}$ & - \\
\hline- & $\begin{array}{l}\text { Dimension Data Holdings } \\
\text { Ltd (37) }\end{array}$ & $\begin{array}{l}\text { Dimension Data Holdings } \\
\text { Ltd (35) }\end{array}$ \\
\hline & Dorbyl Ltd (35) & - & Dorbyl Ltd (36) \\
\hline & Engen Ltd (36) & Engen Ltd (38) & - \\
\hline & Foodcorp Ltd (37) & Foodcorp Ltd (39) & - \\
\hline & McCarthy Retail Ltd (38) & McCarthy Retail Ltd (40) & - \\
\hline & $\begin{array}{l}\text { Murray \& Roberts Holdings } \\
\text { Ltd (39) }\end{array}$ & - & $\begin{array}{l}\text { Murray \& Roberts Holdings } \\
\text { Ltd (37) }\end{array}$ \\
\hline & $\begin{array}{l}\text { Plate Glass \& Shatterprufe } \\
\text { Industries Ltd (40) }\end{array}$ & $\begin{array}{l}\text { Plate Glass \& Shatterprufe } \\
\text { Industries Ltd (41) }\end{array}$ & - \\
\hline & Polifin Ltd (41) & Polifin Ltd (42) & - \\
\hline & Premier Group Ltd (42) & Premier Group Ltd (43) & - \\
\hline & $\begin{array}{l}\text { South African Druggists Ltd } \\
(43)\end{array}$ & $\begin{array}{l}\text { South African Druggists Ltd } \\
(44)\end{array}$ & - \\
\hline- & Toyota South Africa Ltd (45) & $\begin{array}{l}\text { Toyota South Africa Ltd } \\
(38)\end{array}$ \\
\hline - & $\begin{array}{l}\text { Woolworths Holdings Ltd } \\
\text { (46) }\end{array}$ & $\begin{array}{l}\text { Woolworths Holdings Ltd } \\
(39)\end{array}$ \\
\hline & - & & \\
\hline
\end{tabular}

\begin{tabular}{|l|l|l|l|}
\hline & Selected once & Selected once & Selected once \\
\hline & Alpha Ltd (44) & ICS Holdings Ltd (47) & Allied Technologies Ltd (40) \\
\hline $\begin{array}{l}\text { Distillers Corporation (SA) } \\
\text { Ltd (45) }\end{array}$ & $\begin{array}{l}\text { Johnnies Industrial } \\
\text { Corporation Ltd (48) }\end{array}$ & $\begin{array}{l}\text { Amalgamated Beverage } \\
\text { Industries Ltd (41) }\end{array}$ \\
\hline Kohler Ltd (46) & $\begin{array}{l}\text { New Africa Investments Ltd } \\
(49)\end{array}$ & Comparex Holdings Ltd (42) \\
\hline Pep Ltd (47) & $\begin{array}{l}\text { Persetel Q Data Holdings } \\
\text { Ltd (50) }\end{array}$ & Ellerine Holdings Ltd (43) \\
\hline & Sentrachem Ltd (48) & - & $\begin{array}{l}\text { New Clicks Holdings Ltd } \\
(44)\end{array}$ \\
\hline
\end{tabular}




\begin{tabular}{|l|l|l|l|}
\hline & Selected once & Selected once & Selected once \\
\hline & Siltek Ltd (49) & - & OTK Holdings Ltd (45) \\
\hline & $\begin{array}{l}\text { Stellenbosch Farmers' } \\
\text { Winery Ltd (50) }\end{array}$ & - & Primedia Ltd (46) \\
\hline & & - & Super Group Ltd (47) \\
\hline & & - & Trencor Ltd (48) \\
\hline & & - & Truworths Ltd (9) \\
\hline & & - & Waco International Ltd (50) \\
\hline
\end{tabular}

\section{Bibliography}

Blumberg, R. 1995. The accounting standard setting process in South Africa, Unpublished report prepared by Project Director: Accounting, South African Institute of Chartered Accountants, pp.1-2.

Companies Act. 1973. Act number 61 of 1973 (as amended), Government Gazette.

Financial Mail. 1997. Financial Mail Special Survey - Top Companies, 27 June 1997, Financial Mail, Rosebank.

Financial Mail. 1998. Financial Mail Special Survey - Top Companies, 26 June 1998, Financial Mail, Rosebank.

Financial Mail. 1999. Financial Mail Special Survey - Top Companies, 25 June 1999, Financial Mail, Rosebank.

IASC (International Accounting Standards Committee). 1995. Annual review, IASC, London.

IASC (International Accounting Standards Committee). 1996a. An issues paper prepared by the IASC staff, Interim financial reporting, May 1996, IASC, London.

IASC (International Accounting Standards Committee). 1996b. Early decisions on interim financial reporting, IASC Insight, July 1996, pp.14-15.

IASC (International Accounting Standards Committee). 1996c. A draft statement of principles issued for comment by the steering committee on interim financial reporting, Interim financial reporting, September 1996, IASC, London.

IASC (International Accounting Standards Committee). 1997a. Earnings per share - IAS 33, January 1997, IASC, London.

IASC (International Accountancy Standards Committee). 1997b. Statement of principles, Interim financial reporting, March 1997, IASC, London. 
IASC (International Accounting Standards Committee). 1997c. Presentation of financial statements - IAS 1, July 1997, IASC, London.

IASC (International Accounting Standards Committee). 1997d. Proposed international accounting standard, Interim financial reporting - Exposure Draft E57, August 1997, IASC, London.

IASC (International Accounting Standards Committee). 1997e. Leases IAS 17, October 1997, IASC, London.

IASC (International Accounting Standards Committee). 1998. Interim financial reporting - IAS 34, February 1998, IASC, London.

JSE (Johannesburg Stock Exchange). 1995. The Johannesburg Stock Exchange Listing Requirements, June 1995, JSE, Johannesburg.

Koen, M., Botha W.J.J. and Nieuwoudt M.J. 1998. An Accounting and Auditing Perspective on Interim Financial Reporting in the Republic of South Africa, 2nd edition, School of Accountancy Research Series, University of Pretoria, School of Accountancy, Pretoria.

Koen, M., Botha W.J.J. and Nieuwoudt M. J. 1999. An Accounting and Auditing Perspective on Interim Financial Reporting in the Republic of South Africa, 3rd edition, School of Accountancy Research Series, University of Pretoria, School of Accountancy, Pretoria.

Koen, M., Botha W.J.J. and Nieuwoudt M. J. 2000. An Accounting and Auditing Perspective on Interim Financial Reporting in the Republic of South Africa, 4th edition, School of Accountancy Research Series, University of Pretoria, School of Accountancy, Pretoria.

Mockler, K.G. 1993. Newsletter to members from the chief executive, Letter, 10 December, SAICA, Johannesburg, pp.1-4

Nieuwoudt M. J. and Koen, M. 1999. Interim financial reporting in transition, Meditari, Vol 7, pp.187-207.

SAICA (South African Institute of Chartered Accountants). 1990. Framework for the preparation and presentation of financial statements AC 000, November 1990, SAICA, Johannesburg.

SAICA (South African Institute of Chartered Accountants). 1996. Separately disclosable items of income or expenditure within profit or loss from ordinary activities - AC 307, March 1996, SAICA, Johannesburg.

SAICA (South African Institute of Chartered Accountants). 1998a. Presentation of financial statements - AC 101, October 1998, SAICA, Johannesburg. 
SAICA (South African Institute of Chartered Accountants). 1998b. Earnings per share - AC 104, October 1998, SAICA, Johannesburg.

SAICA (South African Institute of Chartered Accountants). 1998c. Interim financial reporting - AC 127, December 1998, SAICA, Johannesburg.

SAICA (South African Institute of Chartered Accountants). 1999. Leases AC 105, December 1999, SAICA, Johannesburg. 